\title{
Two-and-a-Half Cheers for Bush $v$ Gore
}

\author{
Michael W. McConnell $\dagger$
}

By Inauguration Day, 2001, press recounts indicated that George W. Bush almost certainly would have won the election in Florida even if Vice President Gore had gotten everything his lawyers asked for in court. Gore asked for inclusion of the certified recounts in Broward County (567 votes), inclusion of the late recount in Palm Beach County (176 votes $)$, and inclusion of a partial recount of all ballots in the most heavily Democratic areas of Miami-Dade County (168 votes). ${ }^{2}$ That left him 193 votes short of victory (disregarding the Bush campaign's legal objections to many of these results, and ignoring an uncertain number of still-uncounted foreign absentee ballots). Gore's hopes, therefore, were pinned on his remaining demand: for a manual recount of the so-called "undervotes" in the remaining sections of $\mathrm{Mi}$ ami-Dade County. ${ }^{3}$ On January 15, the Associated Press reported that an examination of all 10,600 "undervotes" in Miami-Dade County, conducted by newspaper reporters paired with county elections staff, produced a net gain of six votes for Bush. That means Gore lost.

Paradoxically, Gore's only chance of victory in a recount would have required rejection of his legal position. In the United States Supreme Court, Gore's lawyer David Boies specifically stated that there was no legal basis for counting "overvotes," and the Gore lawyers never sought recounts in more heavily Republican areas. ${ }^{6}$ But a press

$\dagger$ Presidential Professor, University of Utah College of Law.

1 Some reports put this number at 215, but apparently were not correct. See Stuart Taylor, Jr., Why the Florida Recount was Egregiously One-Sided, Natl J 3932 (Dec 23, 2000) (noting how the 176 number, not 215 , was correct).

2 I put aside claims involving Nassau, Seminole, and Martin Counties that were rejected on the merits and not revived by the Florida Supreme Court.

3 "Undervote" was the word used by the Gore legal team for ballots in which voters failed to mark their ballots in such a way as to be readable by the counting machines. Some of these were deliberate decisions not to cast a ballot for president. Some presumably reflected voter confusion or problems with the voting machinery. "Overvote" was the term used for ballots in which voters marked more than one candidate for president.

4 Review Shows Bush Gained 6 Votes in Miami-Dade County, Fla Times Union B3 (Jan 16, 2001). This means that Gore not only would not have gained votes from the recount in the remaining precincts in Miami-Dade, but that he was not entitled to the 168 votes the Florida Supreme Court certified on the basis of the partial recount. See Gore v Harris, 772 S2d 1243, 1262 (Fla Dec 8, 2000) (requiring that the results of the partial Miami-Dade recount be included in the final tally of votes), revd and remd as, Bush v Gore, $121 \mathrm{~S} \mathrm{Ct} 525$ (2000) (per curiam).

5 Transcript of Oral Argument, Bush v Gore, No 00-949, *62-63 (Dec 11, 2000) (available on Lexis at 2000 US Trans Lexis 80 ).

6 Indeed, in Gore $v$ Harris, Gore's lawyers presented as one of the grounds for appeal the 
recount in Lake County, which went for Bush, suggests that the richest source of additional votes for Gore would have been the "overvotes" in Republican-dominated counties using optical scanning vote systems. ${ }^{7}$ It is unclear whether these votes would have been numerous enough to overcome Bush's advantage. ${ }^{8}$ In any event, Gore did not ask that they be counted, and the Florida Supreme Court did not require it.

Thus, we can now say with some confidence not only that Bush won under the law as interpreted by the United States Supreme Court, but he would have won even if Gore had prevailed in his Florida contest action. But this knowledge has not quelled criticism of the way the election was handled. Many Americans believe that Gore somehow would have prevailed if only the United States Supreme Court had allowed the Florida courts to continue the vote counting process. Of course, many other Americans believe just as passionately that the United States Supreme Court prevented the Florida courts from fabricating enough votes to swing the election in Gore's favor.

Anger at the Court was fueled by the apparently partisan breakdown of the vote regarding the proper remedy. The five justices who voted to end the recounting process were all appointed by Republican presidents, and are regarded as the most conservative members of the Court. To cynical eyes, that rendered their votes in favor of the Bush legal position suspect. Of course, the charge of partisanship can be hurled with equal force in both directions: the justices who voted in favor of the Gore legal position were the most "liberal" of the Court, and may have had their reasons for preferring a Gore victory. In many eyes, the whole affair exposed the Court as an untrustworthy institution. In the words of Justice John Paul Stevens: "Although we may never know with complete certainty the identity of the winner of this year's presidential election, the identity of the loser is perfectly clear.

trial court's ruling that "in a contest proceeding in a statewide election a court must review all the ballots cast throughout the state, not just the contested ballots." Gore v Harris, 772 S2d at 1252.

7 See David Damron, Ramsey Campbell, and Roger Roy, Gore Would Have Gained Votes in GOP Stronghold: "Overvotes" Counted Elsewhere, Orlando Sentinel A1 (Dec 19, 2000). It turns out that significant numbers of Democratic voters (a net 130 votes out of more than 6,000 discarded ballots in a heavily Republican county) both darkened the circle for Gore on the ballot and wrote his name as a write-in. Machines registered these as spoiled ballots.

8 Ballots containing this error were already counted in some Florida counties. See Gore $v$ Harris, 773 S2d 524, 535 n 26 (Fla Dec 22, 2000) (Pariente concurring). Moreover, according to press recounts, Bush gained votes in other counties. See Alan Scher Zagier, Bush Easily Tops Gore in Collier Hand Recount, Naples Daily News (Jan 20, 2001), available online at <http://naplesnews.com/01/01/naples/d579324a.HTM > (visited Jan 25, 2001) (reporting net gain of 226 votes for Bush in Collier County). 
It is the Nation's confidence in the judge as an impartial guardian of the rule of law."'

As one who thinks that the judiciary has played an overly large role in American public life over the past few decades, often cloaking the judges' own opinions in a thin veneer of law, I am inclined to think that a dose of realism about the human frailties of the judiciary is not entirely unwelcome. But I fear that rather than stimulating serious reflection on the role of the Court, Bush v Gore ${ }^{10}$ may exacerbate the already corrosive cynicism about public institutions and undermine public faith in the rule of law itself. Before we leap to conclusions about the outcome of Bush $v$ Gore, based on nothing but the pattern of votes, we need to take a closer look at what the Court did.

Litigation over the election came in two rounds. In both rounds, state or local election officials made certain decisions, which were challenged in court either by the Gore campaign or by Democraticmajority county boards. In the trial courts, those decisions were upheld by local state court judges (all of them Democrats). In the Florida Supreme Court, which is composed entirely of Democratic appointees, Gore's lawyers found a more sympathetic ear. On grounds that seemed dubious at best and disingenuous at worst, the Florida court ruled each time in favor of Gore. That put the U.S. Supreme Court in an awkward position. It could either allow a state court to decide the national presidential election through what appeared to be one-sided interpretations of the law, or render a decision that would call its own position, above politics, into question.

I believe the Court deserves two-and-a-half cheers for its performance. But the half cheer it forfeited, by failing to produce a bipartisan consensus on the remand issue, continues to cast long shadows both on the Court and on the Bush presidency.

The Court's first, unanimous ruling was masterful." It reminded the Florida Supreme Court that its decisions were subject to review on federal grounds and-in effect-warned the court that its handiwork in the first round of litigation was not sufficiently attentive to the law. At the same time, the Court decided nothing of practical consequence, and certainly could not be accused of doing anything that swayed the electoral outcome. Unfortunately, the Florida Supreme Court did not take the hint. In the second round, the Florida court - this time split 43 -again rendered a decision reversing a lower court decision on 
grounds that seemed difficult to square with the law. ${ }^{13}$ This time, it was more difficult for the Supreme Court to correct the error without appearing to determine the ultimate outcome. The Court nonetheless came close. Seven of the justices - including Justice Stephen Breyer, a Clinton appointee and former staffer to Senator Edward Kennedy, and Justice David Souter, a Bush Senior appointee but a regular member of the liberal faction on the Court-agreed with the five conservatives that the terms under which the Florida court ordered the statewide manual recount were unconstitutional. Justice Souter called the recounting procedure "wholly arbitrary," and Justice Breyer declared it implicated "principles of fundamental fairness.", In light of the 7-2 vote, the Court's judgment cannot plausibly be attributed to base partisan motives. As discussed below, the Fourteenth Amendment holding, while not very clearly explained in the hastily prepared opinion, was both sensible and persuasive. This part of the opinion was the most important, and the Court-especially Breyer and Souterdeserve far more credit than they have received for achieving a bipartisan near-consensus on so contentious a question.

But the Court split on remedy. Five justices believed that there was not sufficient time for a remand-a decision they attributed to state law-while two justices maintained that the case should be remanded to the Florida courts to try, if they could, to complete a recount in compliance with constitutional standards. For reasons I will explain below, I think the decision to halt the recount was incorrect as a matter of law (though the question is closer than the Court's critics like to think). But perhaps more important even than law, in this case of high constitutional moment, was the questionable judicial statesmanship of this part of the ruling. The 5-4 split created the appearance-whether or not justified-that the Court voted its politics instead of the law. And it deprived the new president - whichever man it would be-of the public assurance that the results were won in the ballot box and not in the courtroom. In effect, the Court accepted the Florida Supreme Court's premise that a manual recount was necessary, but then invoked a questionable reading of state law to say that no such recount could even be attempted. That is an unsettling conclusion. If the five justices in the majority had joined with Justices Souter and Breyer, and remanded to the Florida courts to conduct a recount under strict constitutional standards, the near unanimity of the decision would have been vastly reassuring to the American people. And 
whichever candidate had won would enter office with far greater public confidence in the legitimacy of his election.

\section{The LEgaL IsSUES}

Opponents of the Supreme Court's decision in Bush v Gore have focused principally on the unseemliness of resolving a presidential election by a split vote in the Supreme Court. It is not obvious why resolving it by a split vote in the state supreme court would be an improvement, and it is not obvious why the split character of the vote impugns the majority position rather than the dissent. For the criticism to make sense, therefore, there must be an assumption not only that the Court was split, but that the majority was wrong. That requires a more detailed examination of the issues. The electoral controversy turned, in the first instance, on state law. Lurking behind the state law, however, are certain principles of federal constitutional law, found in Article II and the Fourteenth Amendment. I will turn first to those principles, then to the two phases of litigation in the Florida courts and the U.S. Supreme Court, then to the question of remedy. I will conclude with some comments on the paradoxically self-defeating character of much of the litigation.

\section{The Federal Constitutional OVERLAY}

Article II, Section 1, Clause 2 of the U.S. Constitution provides: "Each State shall appoint, in such Manner as the Legislature Thereof May Direct, a Number of Electors." By specifying "the Legislature" as the source of state law, this Clause departs from the usual principle of federal constitutional law, which allows the people of each state to determine for themselves how to allocate power among their state governing institutions. This puts the federal court in the awkward and unusual posture of having to determine for itself whether a state court's "interpretation" of state law is an authentic reading of the legislative will.

There is no relevant legislative history explaining why the framers of the Constitution made this departure. There are, however, two apparent functional justifications. First, the provision ensures that the manner of selecting electors will be chosen by the most democratic branch of the state government. The selection of presidential electors need not be directly democratic; the legislature could select the electors itself, or even delegate that authority to a more limited body (sub- 
ject to whatever limits the Republican Form of Government Clause ${ }^{16}$ may impose). But by vesting the authority to choose the mode of selection in the most democratic branch, the framers gave that decision a democratic bias.

Second-and more relevant for our purposes-legislatures, in contrast to courts and executive officials, must enact their rules in advance of any particular controversy. A legislative code is enacted behind a veil of ignorance; no one knows (for sure) which rules will benefit which candidates. To use examples from Election 2000, no one could have guessed in advance which candidate would favor strict enforcement of vote counting deadlines, no one could have guessed which candidate would benefit from counting ambiguous chads and dimples as votes, and no one could have guessed how the choice between optical scanning and punchcard voting systems would affect the relative positions of the candidates. To be sure, this veil of ignorance is only partially opaque: it is sometimes possible to make an educated guess about the probable partisan consequences of particular electoral rules. For example, favorable rules for recognizing absentee ballots from abroad could be expected to benefit Republicans, and easy registration of voters could be expected to benefit Democrats. Partisan calculation therefore can play a role. By requiring the manner of selection of electors to be specified in advance by the legislature, however, the Constitution limits the ability of political actors to rig the rules in favor of their candidate.

Courts and executive officials making judgments after the fact operate behind no such veil of ignorance. The officials counting dimpled chads in Broward County knew precisely which candidate would be advantaged by what rule-and indeed, how many votes they needed to discover to put their favored candidate over the top. (By all appearances, they changed standards until they found the one that would produce the desired results.) The members of the Florida Supreme Court knew (or at least thought they knew) which candidate would gain if they extended the vote-counting deadline. They knew this because one candidate was asking for the extension and the other was opposing it. And the U.S. Supreme Court knew who would be elected president if the manual recount were put to an end. Under such circumstances, there is inevitably the danger that a rule will be adopted because it will produce a particular result, and then rationalized on other grounds.

I do not claim that all decisions made under such circumstances are unfair. But when the decisionmaker faces a set of interpretive options, each of which is plausible in the abstract but has predictable ef- 
fects on the electoral outcome-a matter as to which no decisionmaker is neutral-it would not be surprising to find that their judgment is affected. And even if it is not, there will be no way to prove it to the disappointed faction.

Thus, there is wisdom in the provision of Article II, which places authority to set electoral rules in the institution least able to manipulate the rules to favor a particular candidate. Justice Ginsburg is correct that, in ordinary cases, federal courts must defer to state courts with regard to interpretations of state law. ${ }^{17}$ But in this unique context, there is a constitutionally-based federal interest in ensuring that state executive and judicial branches adhere to the rules for selecting electors established by the legislature, and do not use their interpretive and enforcement powers to change the rules after the fact. (I strongly suspect that, if a state supreme court composed entirely of Republican appointees had rendered crucial decisions of dubious legal validity, which had delivered the state to Bush, Justices Stevens and Ginsburg, and many others who complained of Supreme Court meddling, would have seen the necessity of federal court review.)

The second relevant federal constitutional principle is that of equal protection and due process of law. ${ }^{18}$ As a matter of original meaning, it is highly questionable that the Fourteenth Amendment was intended to apply to voting rights. ${ }^{19}$ And there was something to be said for Justice Frankfurter's argument that federal courts should avoid these unanswerable political questions altogether. ${ }^{20}$ The reaction to Bush v Gore (praise by Republicans, denunciation by Democrats) lends weight to Frankfurter's prediction that courts could not enter the political thicket and still maintain their apolitical character, or the appearance of it. But those are old arguments, long rejected by the Court. The right to vote has been recognized as a fundamental right, and strict scrutiny is applied to ensure that every citizen within the jurisdiction is treated precisely equally with regard to that right. ${ }^{21}$

This principle has never been applied in the context of a presidential election before, nor has the Supreme Court addressed the problem of differing voting systems and methods of vote counting.

17 Bush v Gore, $121 \mathrm{~S} \mathrm{Ct}$ at 549 (Ginsburg dissenting).

18 US Const Amend XIV, $\$ 1$.

19 Reynolds $v$ Sims, 377 US 533, 593-611 (1964) (Harlan dissenting) (thoroughly discussing the history and language of the Fourteenth Amendment, concluding it does not apply to state voting rights); Michael W. McConnell, The Redistricting Cases: Original Mistakes and Current Consequences, 24 Harv J L \& Pub Pol 103, 110 (2000).

20 Baker v Carr, 369 US 186, 266-68 (1962) (Frankfurter dissenting).

21 See, for example, Dunn v Blumstein, 405 US 330, 336-37 (1972); Kramer v Union Free School District, 395 US 621, 626-27 (1969). 
But the logic of the voting rights cases strongly supports the view that a state must use a consistent protocol for counting votes-or, at least, that it may not be arbitrary in its recognition of legal votes. Seven justices agreed with that principle in Bush v Gore. Were it not for the partisan context in which the issue was first addressed, I do not believe that it would be considered controversial. There is something fundamentally wrong with a system in which one voter's ballot is recognized when the chad is merely dimpled, but an identical ballot by a voter in the same jurisdiction is not recognized. The problem was particularly egregious in the context of Election 2000 in Florida because of the correlation between partisan affiliation and vote-counting rules. The Democrats were advocating a loose standard for recognition of legal votes, as in Broward County, while the Republicans were advocating a strict standard. The predictable result of a standardless recount, therefore, was to skew the results, as officials in Democratic areas applied the loose standard and officials in Republican areas applied the strict standard. ${ }^{22}$ If such a thing happened in an ordinary election-for town clerk, for example-most lawyers, law professors, and judges would treat this as an obvious equal protection (or due process) violation. With this constitutional backdrop, let us look at the various legal controversies in Bush v Gore.

\section{ROUND ONE}

The first round of litigation centered on two issues: whether to permit a manual recount of the votes, and whether to enforce statutory deadlines for vote counting. The Bush campaign argued that manual recounts were not authorized by Florida law except in cases where there was "an error in the vote tabulation." According to Bush, the undervotes at issue in Florida were attributable to the failure of individual voters to comply with voting instructions, rather than to an error in the vote tabulation. The voting machines were not designed to register votes where the chad had not been removed from the ballot card, and thus their failure to do so could not be described as an error. This position found support in an interpretive ruling by the Secretary of State, and later was endorsed by Chief Justice Rehnquist in his concurring opinion in Bush v Gore.

The Florida Supreme Court rejected this argument. ${ }^{25}$ While the question was close, I think this conclusion was within the bounds of

22 See Taylor, Natl $\mathbf{J}$ at 3933 (cited in note 1).

23 Fla Stat Ann $\$ 102.166(5)$ (West 2000).

$24121 \mathrm{~S} \mathrm{Ct}$ at 537 (Rehnquist concurring).

25 See Palm Beach County Canvassing Board v Harris, 772 S2d 1220, 1228 (Fla Nov 21, 2000 ) (holding that plain language of Section 102.166(5) was contrary to the Secretary of State's interpretation), vacd and remd as, Bush v Palm Beach County Canvassing Board, 121 S Ct 471 
reasonable interpretation. The Florida Election Code provides that in conducting a manual recount, the counting team's duty is "to determine a voter's intent in casting a ballot." ${ }^{26}$ Since a ballot cast in full compliance with the voting instructions is highly unlikely ever to raise questions about voter intent, this suggests that manual recounts are expected to include some ballots that were not in compliance with the instructions. This does not necessarily mean that dimples should be counted-they had never been counted in previous Florida elections-but it does provide support for the Florida court's conclusion that manual recounts should include some ballots that were rejected by the machines.

That leaves the question of deadlines. In some elections, it does not matter (much) how long the vote counting process takes. If the county sheriff's term begins a few weeks late, who cares? Election of a president is different. To begin with, in order to prevent gamesmanship among the states, the Constitution empowers Congress to set a uniform date for presidential elections, and requires Congress to set a uniform date on which the electors must meet and vote. ${ }^{27}$ In 2000 , election day was November 7, and the date on which the electors voted was December 18. Any process of counting, recounting, and judicial review must fit within that time frame. Moreover, the practicalities of selecting the president-elect of the world's greatest power militate in favor of a prompt resolution. A smooth transition to a new administration takes time, and uncertainty about who is to be the next president is profoundly unsettling to the nation, and to the world. There is inevitably a balance between time to check and recheck the results and the need for a prompt and definitive resolution; but in this context tight deadlines are rational and must be observed. (Behind a veil of ignorance, I hazard the guess that Democrats, no less than Republicans, would favor a system with tight deadlines for counting presidential ballots. Deadlines become controversial only when it is evident which candidate might gain from having more time for recounting.)

(2000) (per curiam).

26 Fla Stat Ann $\S 102.166(7)(b)$. Oddly, the Florida Supreme Court did not cite this provision of the Election Code, instead referring to a different section, which addressed the problem of preparing duplicate ballots when the original was damaged and unreadable. Gore v Harris, 772 S2d 1243, 1256 (Fla Dec 8, 2000) (citing Fla Stat $\S 101.5614(5)(2000)$ ), revd and remd as, Bush v Gore, $121 \mathrm{~S} \mathrm{Ct} 525$. This contributed to the impression that the state supreme court was playing games with the statute. The court also cited Section 101.5614(6), which provides that a ballot must be counted for other offices even when the vote on one office is not clear.

27 US Const Art II, $\S 1$, cl 4 ("The Congress may determine the Time of chusing the Electors, and the Day on which they shall give their Votes; which Day shall be the same throughout the United States."). 
Florida state law explicitly sets a deadline of seven days after the election for county canvassing boards to count the votes and report the results. ${ }^{28}$ A recent amendment allowed the Secretary of State to waive this deadline, but that decision is left to her discretion, ${ }^{29}$ and she has determined that waivers are appropriate only in very limited circumstances. Her decision was upheld by the circuit court ${ }^{30}$ (in an opinion by a Democratic judge, if that matters), but it was overturned by the Florida Supreme Court in Palm Beach County Canvassing Board v Harris. ${ }^{31}$ In an opinion that was long on words but short on clarity, the Florida court extended the deadline for reporting and certification from November 14 to November $26 .{ }^{32}$

On certiorari to the United States Supreme Court, the Bush campaign made a powerful argument that this decision was contrary to the plain language of the Florida electoral code, and hence in violation of Article II, which vests the legislature - not the courts - with authority to determine the manner for choosing electors. The trouble, however, was that by the time the case got to the High Court, the new deadline had already passed, Governor Bush had been certified the winner, and the legal conflict had moved on to a new phase, rendering Palm Beach County Canvassing Board v Harris all but moot. As already noted, the Supreme Court vacated the decision and remanded to the Florida court for clarification of its legal basis. ${ }^{33}$ This was a powerful warning to the state court that the U.S. Supreme Court was keeping a close eye on its proceedings, and was prepared to intervene if it appeared that the state court were twisting or distorting state law.

The Supreme Court focused on language in the state court opinion that suggested it was relying on state constitutional law-rather than state statutory law - for its decision. ${ }^{34}$ In my opinion, the more substantive problem was not that the Florida court consulted its state constitution in rendering the decision, but that it disregarded the plain language of the statute and substituted a new deadline entirely of its own making. This was obviously not "interpretation." From its denunciation of "hyper-technical reliance upon statutory provisions"

28 Fla Stat Ann $\S \S 102.111,102.112$ (West 2000).

29 Id § 102.112(1).

30 McDermott v Harris, 2000 WL 1714590, *1 (Fla Cir Ct Nov 17), revd as Palm Beach County Canvassing Board v Harris, 772 S2d 1220, vacd and remd as, Bush v Palm Beach County Canvassing Board, $121 \mathrm{~S} \mathrm{Ct} 471$.

31772 S2d 1220, 1228-29 (Fla Nov 21, 2000), vacd and remd as, Bush v Palm Beach County Canvassing Board, $121 \mathrm{~S} \mathrm{Ct} 471$.

32 Palm Beach County Canvassing Board v Harris, 772 S2d at 1240.

33 Bush v Palm Beach County Canvassing Board, $121 \mathrm{~S} \mathrm{Ct}$ at 475.

34 Id at 473-74.

35 Palm Beach County Canvassing Board v Harris, 772 S2d at 1227. 
fabrication of new deadlines out of whole cloth, ${ }^{36}$ the court demonstrated that it would not be bound by the legislature's handiwork. The state court's claim that it was reconciling inconsistent provisions in the statute $^{37}$ was specious. To be sure, one statute said that the Secretary of State "shall" ignore late-filed returns, and another statute said she "may" ignore late-filed returns. ${ }^{39}$ But that provides no support for interpreting the law to say that she "shall not" ignore them, or to authorize the court to create its own deadline. Nor was the court correct to say that the seven-day deadline conflicted, as a practical matter, with the provision allowing a candidate to request a recount as late as five days after the election. ${ }^{40}$ Presumably, a candidate takes a risk if he waits the full five days (how big a risk this is, I will address in a moment). But to call this a "conflict" is like saying a Monday morning deadline for a student research paper "conflicts" with allowing the student to wait until Sunday night to begin work.

More importantly, the state court ripped the deadline issue out of its broader context. The deadline (as I read the statute) is not absolute. It is merely the deadline for completing the pre-certification, or "protest," phase. During this phase, the county canvassing boards have discretion to decide whether to conduct manual recounts. At the end of this phase-seven days after the election - the counties must report to the Secretary of State, who certifies the results. Certification, however, is not the end of the road. After certification, candidates may file election "contests," in which they challenge the decisions of the county boards, including their mistakes in vote counting and their failure to conduct recounts, so long as those decisions involved "rejection of a number of legal votes sufficient to change or place in doubt the result of the election." ${ }^{41}$

The Florida Supreme Court defended its deadline extension on the argument that failing to recognize votes for purposes of certification is tantamount to "disenfranchis[ing]" the voters. ${ }^{42}$ This, the court said, is "unreasonable, unnecessary, and violates longstanding law." So it might be, if certification were the final step in the process. But it is not. Certification is simply the legal step that leads to the "contest" phase, during which disappointed candidates can challenge the results.

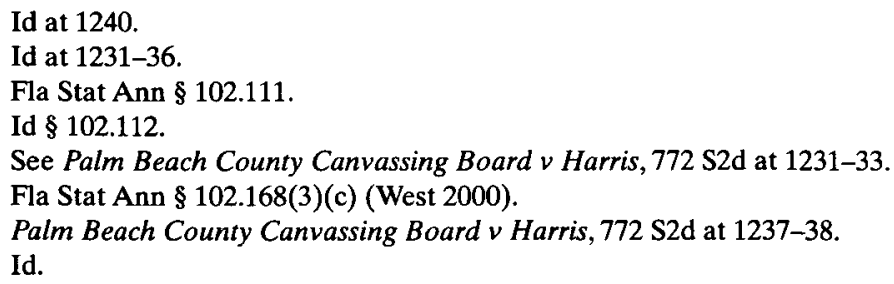


By postponing certification to November 26 , the state court did not prevent "disenfranchisement"; it simply shortened the "contest" phase by more than a week."

Ironically, in its second decision, discussed more fully below, the Florida Supreme Court adopted an interpretation of the "contest" phase that empowered circuit courts to conduct recounts on their own authority, de novo, without regard to the decisions of the county boards. ${ }^{45}$ Under this interpretation of the statutes, the certification of the results by the county boards and the secretary have no legal consequence, except to serve as "evidence," submissions. This made the court's earlier decision to extend the deadline truly perverse. The court added twelve days to a phase that had no real legal significance, while shortening the time for obtaining genuine legal relief. If, as the court held in Gore v Harris, ${ }^{47}$ the state court in the "contest" phase can order manual recounts any time it believes they might affect the result, then it certainly does not "disenfranchise" voters to put a quick end to the pre-certification phase of the proceeding.

In my opinion, the court got it wrong both times. In Palm Beach County Canvassing Board $v$ Harris, the court overstated the importance of certification, and in Gore $v$ Harris, the court understated its importance. Properly interpreted, the pre-certification phase is one in which county officials, under the supervision of the secretary, perform the initial vote count, exercising discretion in such matters as whether to conduct manual recounts. The post-certification phase is styled a "contest" of the certified result, and is in the nature of judicial review of an administrative decision. As in most instances of judicial review of administrative decisions, the administrative decision enjoys a presumption of validity, which the contestant can overcome by a showing that it was an abuse of discretion or contrary to law. This is an intermediate position between Palm Beach County Canvassing Board v

44 Later, in Gore v Harris, the court ruled that the Secretary had to accept county recount results, even when they arrived after the new deadline set by the court. $772 \mathrm{~S} 2 \mathrm{~d}$ at 1262 . Thus, in effect, the court eliminated the deadline altogether.

45 Id at 1252.

46 Id.

47772 S2d 1243 (Fla Dec 8, 2000), revd and remd as, Bush v Gore, 121 S Ct 525.

48 See Krivanek v Take Back Tampa Political Committee, 625 S2d 840, 844-45 (Fla 1993) (" $[T]$ he judgment of officials duly charged with carrying out the election process should be presumed correct if reasonable and not in derogation of the law."); Boardman v Esteva, 323 S2d 259, $268 \mathrm{n} 5$ (Fla 1975) (agreeing with the trial court's observation that "[t]he election process ... is committed to the executive branch of government through duly designated officials all charged with specific duties... [Their] judgments are entitled to be regarded by the courts as presumptively correct."); Broward County Canvassing Board v Hogan, 607 S2d 508, 510 (Fla Dist Ct App 1992) ("The statutes clearly leave the decision to conduct a manual recount within the discretion of the board."). 
Harris, which assumed that the certified results were conclusive, and Gore v Harris, which treated them as legally irrelevant.

At the time, Palm Beach County Canvassing Board $v$ Harris looked like a devastating blow to Bush. It gave more time to the county canvassing boards in certain Democratic counties-all dominated by Democratic officials - to "find" just enough votes to put Gore over the top, and it shortened the time that the disappointed candidate-probably Bush - would have to challenge these decisions in court. The most likely scenario was that the Democratic boards would deliver the necessary votes, and that the clock would run out precisely at the point when Republicans were challenging judgment calls that were made by political bodies loaded against them. The Florida courts would then choose between disregarding Republican protests (or treating them summarily) and risking Florida's representation in the electoral college. It looked very bad for Bush.

As it turned out, the decision injured Gore instead of Bush. Palm Beach County could not complete its recount even under the new deadline, and Miami-Dade (after a slow beginning) did not even try. (My suspicion at the time ${ }^{49}$-now corroborated by events - was that the experienced politicians conducting the Miami-Dade recount realized from the partial recount that Bush, not Gore, would benefit from completing the recount, and thus decided not to bother.) Thus, when the new deadline passed, Bush remained in the lead; it was Gore, not Bush, who was in the position of contesting the certified results; and it was Gore, not Bush, who needed more time at the end. If the contest period had not been shortened by over a week, and all else had remained the same, there might have been time to conduct a constitutionally proper recount after the final decision in Bush v Gore. Like a boomerang, Gore's strategy had reversed its course and smitten its creator.

\section{ROUND Two}

The second round of litigation occurred after certification. On November 26, the new deadline set by the Florida Supreme Court, Secretary Harris certified the electoral result, finding Bush to be ahead of Gore by 537 votes. This result was affirmed by the state trial court, essentially on the ground that Gore had failed to show any

49 See Alan Brinkley and Michael McConnell, Dialogue: What Now?, Slate Magazine (Nov 28,2000 ), available online at <http://slate.msn.com/dialogues/00-11-15/dialogues.asp?iMsg=16> (visited Feb 22, 2001). 
abuse of discretion. ${ }^{\text {s0 }}$ In the Florida Supreme Court, a 4-3 majority held that Gore was entitled to the relief he had requested: inclusion of results of a late recount in Palm Beach and a partial recount in MiamiDade, and an order requiring a recount in the rest of Miami-Dade." The court also ordered a statewide recount of all "undervotes," which neither party had requested. ${ }^{52}$ The court declined to set any standard (beyond the "intent of the voter") to guide the recount. ${ }^{53}$ Moreover, without stating any reasons, the court rejected Bush's challenges to the recounts in Broward and Volusia Counties, and to the results of the partial recount in Miami-Dade, all of which relied on an expansive definition of what properly counts as a legal vote.

There were multiple problems with this ruling. To begin with, the court treated the contests as de novo proceedings. ${ }^{54}$ This replaced a process in which local governing bodies were the principal vote counting authorities, ${ }^{s s}$ subject to supervision by the Secretary of State and judicial review, under an abuse of discretion standard, ${ }^{36}$ with a process in which the courts themselves conduct the vote counting in close elections. That seems a significant change in the law. Moreover, the court brushed aside a set of statutory safeguards for manual recounts, including the requirement that "all ballots" be included in any manual recount," that recounting be conducted by bipartisan panels "when possible," and that any disagreements regarding voter intent be resolved by the county canvassing boards, ${ }^{59}$ subject to judicial review. ${ }^{60}$ Under the court-ordered recount, only undervotes would be counted, ${ }^{61}$ the panels were to be composed of anyone the court could find to do

50 Gore v Harris, 2000 WL 1790621, *4 (Fla Cir Ct Dec 3), revd and remd as Gore v Harris, 772 S2d 1243 (Fla Dec 8, 2000), revd as Bush v Gore, 121 S Ct 525.

51 Gore v Harris, 772 S2d at 1262.

52 Id.

53 Id at 1252.

54 Id at $1252,1260$.

55 Fla Stat Ann $\S \S 102.131,102.141$ (2) (West 2000).

56 Id $\S 97.012$ (1) (authority of Secretary of State); id § 102.168(1) (judicial review in contest proceedings). On the abuse of discretion standard, see cases cited in note 48.

57 Id $\S 102.166(5)(c)$.

58 Id $\$ 102.166(7)(a)$.

59 Id $\S 102.166(7)(\mathrm{b})$

60 Id $\$ 102.168(3)(\mathrm{e})$. To be sure, these statutory safeguards pertain to manual recounts ordered by county canvassing boards during the protest phase, and not (expressly) to recounts ordered by circuit courts in the contest phase. But the only statutory authorization for manual recounts appears in the code sections pertaining to the protest phase. There is no reason to assume that the safeguards for manual recounts were intended to disappear in the post-certification period. The more likely interpretation is that the court in a contest phase is limited to hearing "contests" to the certified results, and if the court concludes that the county board should have conducted a manual recount, it should order such relief-in accordance with the statutory procedures for manual recounts specified in Sections 102.166(5)(c) and 102.166(7).

61 See Gore v Harris, 2000 WL 1811188, *24 (Fla Cir Ct Dec 8) (Lewis). 
the job, ${ }^{62}$ party observers would be prohibited from lodging oral objections during the vote counting process, ${ }^{63}$ and no written record would be kept of decisions regarding particular ballots, thus rendering appeals virtually impossible. That seems a significant change in the law. Perhaps most strikingly, the court held that the recount should be statewide, and conducted under the supervision of a single circuit judge. $^{65}$ Neither Bush nor Gore requested this statewide recount, and it is hard to see how the appellate court had the authority to order it. Contest proceedings take the form of legal challenges to the decisions of county canvassing boards, which are denominated the defendants in the contest actions. ${ }^{66}$ How could the Florida Supreme Court order review of the certified results from counties whose results had not been contested, and which were not parties to the litigation?

Any of this could have been the basis for a persuasive finding of an Article II violation. But the Article II argument attracted only three votes on the U.S. Supreme Court, ${ }^{67}$ and I shall address it no further.

The key problem with the decision turned out to be the court's failure to specify a consistent and uniform standard for recognition of legal votes. With some vote counters recognizing dimpled chads, and other vote counters following more restrictive principles, there was no way that the state-ordered recount could produce a fair and accurate result. Moreover, by certifying the results from Palm Beach as well as Broward and Volusia Counties, the court effectively ensured that the statewide recount would reflect very different vote counting standards. Palm Beach treated a "dimpled chad" as a legal vote only if there were extrinsic evidence that this was the voter's intent (for example, if there were similar dimples for other offices on the ballot). ${ }^{68}$ By contrast, in a series of 2-1 party-line votes, the Broward County Board recognized dimples as votes without regard to extrinsic evidence of voter intent, producing, on average, more than three times as many votes per 100 disputed ballots as were recognized in Palm

62 See id at $* 25$.

63 See id.

64 See id.

65 See Gore v Harris, 772 S2d at 1261-62.

66 Fla Stat Ann $\S 102.168$ (4). See Gore v Harris, 772 S2d 524, 532 (Fla Dec 22, 2000) (Pariente concurring) (pointing out that there is no procedure in Florida law for obtaining a statewide manual recount).

67 See Bush v Gore, $121 \mathrm{~S} \mathrm{Ct}$ at 533-39 (Rehnquist concurring).

68 See Tina Cassidy, Election 2000/Court Date: Democrats Plan Legal Challenge of Tallies in 3 Counties, Boston Globe A10 (Nov 27, 2000). 
Beach. ${ }^{69}$ In addition, the Florida Supreme Court certified the results of the partial recount in Miami-Dade, based on an examination of all the ballots in the most heavily Democratic precincts, ${ }^{70}$ even though the recount in the more Republican areas would include only the undervotes. Gore gained 490 more votes in Broward and Miami-Dade than he would have gained from application of the Palm Beach standard." That could easily have been the margin of victory, if the statewide recount had found a few hundred more. Remarkably, the Florida court did not even mention Bush's challenges to these votes-let alone explain why they were being rejected.

It was no surprise, therefore, that the United States Supreme Court stepped in. The per curiam opinion described the recount as "inconsistent with the minimum procedures necessary to protect the fundamental right of each voter." Justice Souter, who voted to deny the petition for certiorari and disagreed vehemently with the majority on all other issues, conceded that this disparity in vote counting standards, which he described as "wholly arbitrary," was "a meritorious argument for relief.," He stated that he could "conceive of no legitimate state interest served by these differing treatments of the expressions of voters' fundamental rights." "He "would therefore remand the case to the courts of Florida with instructions to establish uniform standards for evaluating the several types of ballots that have prompted differing treatments." Justice Breyer, who like Justice Souter disagreed with the decision to grant certiorari and with the remainder of the Court's decision, concluded that the lack of uniform vote counting standards "does implicate principles of fundamental fairness." " $\mathrm{He}$ went out of his way to note that an "appropriate remedy" would not only entail "the adoption of a uniform standard" but also new recounts in Broward, Volusia, Palm Beach, and Miami-Dade Counties "whether or not previously recounted." This was evidently a response to Bush's argument that the recounts in these counties had been improperly conducted.

69 See Mike Williams, Florida Certifies Bush Win but Court Battles Continue, Atlanta J \& Const 1A (Nov 27, 2000).

70 The 135 precincts included in the recount (out of 614 precincts in the county) registered a 74 percent vote for Gore. The county as a whole went for Gore 53 percent to 47 percent. See John Fund, The Myth of Miami (Nov 26, 2000), available online at <http://www.opinionjournal. $\mathrm{com} /$ diary/?id $=65000686>$ (visited Feb 22, 2001).

71 For the derivation of these numbers, see Taylor, Natl J at 3932-33 (cited in note 1).

72 Bush v Gore, $121 \mathrm{~S} \mathrm{Ct}$ at 532.

73 Id at 545 (Souter dissenting).

74 Id.

75 Id.

76 Id at 551 (Breyer dissenting).

77 Id 
Were it not for the press of time, and the majority's decision not to allow the state courts to conduct a recount under proper constitutional standards, I do not believe this holding would strike many observers as controversial. It may be true that the Equal Protection Clause typically protects against discrimination against identifiable groups, but as recently as last year, the Court summarily affirmed the principle that it also protects against "irrational and wholly arbitrary" state action, even where the plaintiff does not allege that the unequal treatment was on account of "membership in a class or group." And in cases involving fundamental rights, such as the right to vote, the Court applies strict scrutiny to all disparities, without regard to whether the disparities reflect discrimination against any protected group. Minor and unsystematic variances from precise population equality for legislative districts injure no identifiable group, but nonetheless violate the Equal Protection Clause. ${ }^{80}$ Similarly, to treat one voter's ballot as a legal vote, and another voter's identical ballot as spoiled, in the same jurisdiction, for no conceivable public purpose, certainly states a plausible equal protection claim.

Even Justice Stevens, joined by Justice Ginsburg in dissent, acknowledged that "the use of differing substandards for determining voter intent in different counties employing similar voting systems may raise serious concerns." ${ }^{,{ }^{81}}$ They declined to find a constitutional violation, however, on the ground that " $[\mathrm{t}]$ hose concerns are alleviated - if not eliminated - by the fact that a single impartial magistrate will ultimately adjudicate all objections arising from the recount process." ${ }^{, 82}$ That assurance rings hollow in the circumstances of this case, where Leon County Circuit Judge Terry Lewis announced that he would not set or enforce a uniform standard, where partisan observers were not permitted to voice objections as disputed ballots were counted, where vote counters maintained no written records of the disposition of disputed ballots, on which an appeal to Judge Lewis might be based, and where the pace of events would scarcely allow him to exercise review over some sixty thousand ballots.

78 Village of Willowbrook $v$ Olech, $120 \mathrm{~S} \mathrm{Ct} 1073,1074-75$ (2000).

79 See Laurence H. Tribe, American Constitutional Law $\S 16-7$ at 1454 (Foundation 2d ed 1988).

80 See Karcher v Daggett, 462 US 725, 744 (1983). Of course, it could be said that the injured "group" is residents of the larger districts. But that is analytically analogous to saying that voters with uncounted votes were the injured group in Bush v Gore.

81 Bush v Gore, $121 \mathrm{~S} \mathrm{Ct}$ at 541 (Stevens dissenting).

82 Id.

83 Gore v Harris, 2000 WL 1811188 at *24-26. 
Critics make a slippery slope argument: that if different standards for vote counting are unconstitutional, this would render the use of different voting systems by different counties unconstitutional. ${ }^{84}$ I think not, for two reasons. First, the Equal Protection Clause requires equality of treatment within a jurisdiction, but not between jurisdictions. ${ }^{85}$ Florida law delegates authority over elections to counties, and there is no constitutional problem if different counties adopt different voting systems. The constitutional issue arose in this election because the Florida Supreme Court (in my opinion erroneously, as a matter of state law) consolidated statewide vote-counting authority in a single jurisdiction, Leon County Circuit Court, without requiring a uniform standard for vote counting within that jurisdiction. Second, there are some aspects of the administration of elections that cannot be remedied after the fact without conducting a revote, which is a drastic remedy never required in the absence of intentional fraud or other extraordinary circumstances. If the use of different voting machines by different counties raises a constitutional issue, it must be challenged before the election, when it could be remedied. Protocols for vote counting are an entirely different matter, since differences can easily be remedied by institution of a uniform standard.

But even if these slippery slope arguments were more persuasive, they would not carry the day because the bottom of the slippery slope is not particularly unattractive. Why not require every state to adopt a uniform vote counting system? Every voting system has its flaws, but in ordinary cases the effects are randomly distributed. The problem in Florida arose because the optical scanning system is predominantly used in more Republican areas, while the punchcard system is predominantly used in more Democratic areas. Thus, the errors were not randomly distributed. We may not know the perfect voting system, but we could solve most of the problem by requiring that the same system be used throughout the state. Then the random errors would not matter.

\section{THE REMEDY}

On the merits, then, the Court's 7-2 decision to reverse the Florida Supreme Court's decision was well founded. But the same cannot

84 See, for example, Bush v Gore, $121 \mathrm{~S} \mathrm{Ct}$ at 541 (Stevens dissenting).

85 This is the implicit, and convincing, explanation for the holdings of San Antonio Independent School District v Rodriguez, 411 US 1, 55 (1973) (ruling that a state's use of property taxation for school funding did not violate the Equal Protection Clause), and Milliken v Bradley, 418 US 717, 745 (1974) (ruling that district court could not impose a multidistrict remedy in a single district de jure school segregation situation). The ostensible explanation in Rodriguezthat education is not a fundamental right and poverty is not a suspect class-is unconvincing. 411 US at 17-18. I cannot believe a court would hold there is no violation if a school district deliberately provided a less valuable education to poor children. 
be said of the decision not to allow the lower court to attempt a recount under constitutionally appropriate standards. Had the Court majority accepted the Article II theory that the Florida court misread Florida law in ordering a manual recount to correct individual voter error rather than errors in vote tabulation, it would have been logical to stop the recounting process. ${ }^{86}$ But there were only three votes for that theory of the case. Having rested the decision on the standardless character of the recount ordered by the state court, the logical outcome was to remand under proper constitutional standards.

The per curiam opinion explained its conclusion about the remand as follows:

The Supreme Court of Florida has said that the legislature intended the State's electors to "participat[e] fully in the federal electoral process," as provided in 3 U.S.C. $\$$ 5. [772] So.2d, at - , 2000 WL 1800752 (slip op. at 27); see also Palm Beach Canvassing Bd. v. Harris, [772] So.2d [1220], —, 2000 WL 1725434, *13 (Fla. 2000). That statute, in turn, requires that any controversy or contest that is designed to lead to a conclusive selection of electors be completed by December $12 \ldots$... Because it is evident that any recount seeking to meet the December 12 date will be unconstitutional for the reasons we have discussed, we reverse the judgment of the Supreme Court of Florida ordering a recount to proceed. $^{87}$

Sympathetic as I am to the nation's need for a resolution to the election imbroglio, I do not find that explanation very persuasive. As a matter of federal law, the December 12 date is not a strict deadline, but merely a "safe harbor" date insulating electors chosen by that date from congressional challenge. No doubt the Florida legislature hoped to take advantage of that safe harbor, but it passed no statute embodying that intention. Nor do the two cited Florida Supreme Court opinions supply any authoritative pronouncement that December 12 is the absolute deadline for state law purposes. The first citation, to Gore v Harris, seems to be in error. "The "see also" citation, to Palm Beach County Canvassing Board v Harris, comes closer, but is far from unambiguous.

86 Bush v Gore, $121 \mathrm{~S} \mathrm{Ct}$ at 537-38 (Rehnquist concurring). Most other Article II errors identified by the concurring Justices could, in theory, have been corrected on remand.

87 Bush v Gore, $121 \mathrm{~S} \mathrm{Ct}$ at 533.

88 Nothing on that page, or surrounding pages, seems relevant. See, for example, Gore v Harris, 772 S2d at 1248 (commenting on 3 USC $\S 5$ but not describing it as an absolute deadline).

89 In this passage, the Florida court observes that it would be appropriate for the Secretary of State to disregard late-filed returns if they are "so late that their inclusion will ... preclud[e] 
It might still be true that December 12 is the deadline under state law. Language in support of that conclusion can be found in Palm Beach County Canvassing Board v Harris, ${ }^{\text {, }}$ the Florida Supreme Court's decision on remand from Bush v Gore. This decision was handed down on December 11, the day of oral argument in Bush v Gore, and must not have come to the justices' attention. In footnote 17, the Florida Supreme Court explained that a reasonable time to complete a manual recount would depend on the election, and stated:

In the case of the presidential election, the determination of reasonableness must be circumscribed by the provisions of 3 U.S.C. $\S 5$, which sets December 12,2000 , as the date for final determination of any state's dispute concerning its electors in order for that determination to be given conclusive effect in Congress."

Moreover, in footnote 22, the court referred to December 12 as "the outside deadline." ${ }^{\prime 2}$ These passages may not justify the Supreme Court's decision, since the Court did not rely on them, but they indicate that the Court may have reached the right result for the wrong reason. If the Florida Supreme Court was prepared to recognize December 12 as "the outside deadline," then the same ultimate outcome would have been reached even if the High Court had remanded for further proceedings.

Some commentators have defended the decision to halt the recount on the ground that a continued recount would have produced a constitutional crisis. That was a serious possibility, and may help to explain, even if not to justify, the Court's decision. But I am skeptical. Let us canvass the possible outcomes, in order of their potential for provoking a crisis. First, as now appears most probable, Bush could have won the recount, perhaps by a wider margin. That would have put all reasonable doubts about the election to rest. Second, as appeared most likely at that juncture, there might not have been time enough to conduct a recount under fair and consistent standards, with opportunity for appeals, by the federal constitutional deadline of December $18 .^{93}$ From Gore's point of view, that would have been no im-

Florida voters from participating fully in the federal electoral process," and drops a footnote to 3 USC \$\$ 1-10. Palm Beach County Canvassing Board v Harris, 772 S2d at 1237 n 55. This could be taken as a reference to the safe harbor rule of 3 USC $\S 5$, but that would be a stretch.

90772 S2d 1273 (Fla Dec 11, 2000) (per curiam).

91 Id at $1286 \mathrm{n} 17$.

92 Id at $1290 \mathrm{n} 22$. (I thank Professor James Blumstein for bringing these footnotes to my attention.)

93 In her dissenting opinion in Bush v Gore, Justice Ginsburg suggested that there is no federal deadline short of January 6 , the date on which Congress meets to count the electoral votes. $121 \mathrm{~S} \mathrm{Ct}$ at 550 . With due respect, I think that is plainly incorrect. Article II, $\S 1$, cl $4 \mathrm{em}$ powers Congress to determine the day on which the electors meet to give their votes, and states that this "Day shall be the same throughout the United States." (emphasis added). December 18 
provement over the actual decision, except for a few days' more grief. But it would have deflected attention-and responsibility-from the Supreme Court, which acted as expeditiously as humanly possible, to the process in Florida.

Third, if Gore had won a full and fair recount, then Congress would have been required to choose between two competing slates of electors. The worst scenario, I suppose, is that even after receiving instructions from the Supreme Court regarding constitutionally appropriate vote-counting standards, the Florida court had conducted a recount in an unfair fashion. Either of these scenarios would indeed have produced a constitutional confrontation. A good case can be made, however, that the Constitution and laws have designated Congress - not the Court-as the arbiter of such a conflict. I do not assume that all members of Congress would necessarily vote the party line. Whether following politically contentious-but legalprocedures would constitute a constitutional crisis is not obvious, and might well depend on how Congress rose to the occasion.

\section{HINDSIGHT}

In retrospect, one of the most remarkable features of the Election 2000 controversy was the consistent way in which lawyers misjudged their clients' best interests. I have already discussed the fact that Gore's lawyers asked for the extension of the certification deadline, only to be injured by the concomitant shrinkage of the contest period. But Gore's lawyers' miscalculations went far beyond that. They attempted to gain an advantage by confining their recount requests to a few heavily Democratic counties in south Florida. They did not request a statewide recount, presumably because they assumed that recounts produce more votes, that the new votes would go to the candidates in proportion to their support in the county, and thus that recounts outside the Democratic strongholds would benefit Bush. They did not request recounts of the "overvotes," presumably because these would be more numerous in counties with optical scanning sys-

was so designated by statute. It would be unconstitutional for Congress to allow the electors from a single state to give their votes on a later date. I am aware that in the 1960 presidential election, Congress recognized electors from the state of Hawaii who had been chosen after this deadline. That should not be treated as a precedent. In that election, the votes of Hawaii were not necessary to the result, and on the suggestion of the losing candidate, Vice President Richard Nixon, in his capacity as President of the Senate, were recognized as a courtesy.

94 Some attribute the timing problem to the Supreme Court's grant of a stay on December 9. But this is a red herring. The recount then underway was constitutionally defective, and would have had to be done over, if the stay had not been granted. See Bush v Gore, $121 \mathrm{~S} \mathrm{Ct}$ at 551 (Breyer dissenting). 
tems, which tended to be Republican. They did not seek a uniform standard for vote counting, presumably because they benefited from a subjective standard, which maximized their votes in Democratcontrolled Broward and Volusia Counties, while not swelling Bush votes elsewhere.

These tactics were, in hindsight, a mistake. First, by confining their requests in this fashion, they fostered the cynical impressionprobably true - that they were less interested in a full and fair result than in winning. That was bad for their public relations campaign. Second, by failing to request a statewide recount, they postponed the day on which the Florida courts would ultimately decide that such a recount would be necessary, until it was too late. Third, their failure to seek uniform standards laid the groundwork for the equal protection problem, which ultimately invalidated their recount. Most ironically, we now know that the selective recounts they sought would not have been enough to put Vice President Gore over the top. Their only hope of winning, it now turns out, was to recount the overvotes in predominantly Republican parts of the state-just what they were trying to avoid.

The Bush legal strategy was more coherent. His lawyers and publicists had a theme, and they stuck to it: Bush won the machine count, and any attempt to supplement it by manual recounting was just an invitation to human error or abuse. Whatever the merits of this position, I do not think they won the public relations battle on this point. Too many people were persuaded by the Democratic claims that votes were not counted. Thus, in the end, when the recount was aborted, many millions of Americans were persuaded that President-elect Bush's victory was not legitimate. Now we know that, if the Bush campaign had simply agreed to a limited recount of the contested counties under a fair and uniform standard, the whole affair could have been concluded more quickly, and Bush would have emerged as the undisputed winner. Indeed, in Miami-Dade County, he would even have picked up votes from the recount.

What is the moral of this story? Perhaps that even in the midst of partisan confrontation, it is sometimes best not to pursue what appears, at the moment, to be to your candidate's maximum advantage. If Gore's position had been a little fairer, he might have obtained the recount he thought he deserved. If Bush's position had been a little more accommodating, he might have obtained a more secure mantle of leadership. The nation might have gained, as well, by the spectacle of the two candidates yielding a little, and recognizing at least a part of the justice in the other side's position. That would have been good practice for the coming four years. 